Nigerian Veterinary Journal 2010 Vol 31 (2): 115-123

\title{
HAEMATOLOGICAL PROFILES OF PIGS RAISED UNDER INTENSIVE MANAGEMENT SYSTEM IN SOUTH-EASTERN NIGERIA
}

\author{
*EZE, J. I.; ONUNKWO, J. I.; SHOYINKA, S. V. O.; CHAH, F. K.; NGENE, A. A.; \\ OKOLINTA, N.; NWANTA, J. A.; ONYENWE, I. W.
}

Faculty of Veterinary Medicine, University of Nigeria, Nsukka, Nigeria.

http://www.unn.edu.ng

*Correspondence: E-mail; jamesifeeze@yahoo.com; Tel: +2348057015931

\section{SUMMARY}

The haematological profile of pigs raised under intensive management system in SouthEastern Nigeria was studied. A total of 114 pigs were sampled comprising of 48 males and 66 females. Thirty-seven pigs were sampled in Anambra State, 46 in Enugu State and 31 in Ebonyi State with 38 being piglets and 76 adults. The blood values compared favourably with the reference values except for $\mathrm{MCV}$ and $\mathrm{MCH}$ that were slightly lower than the standard. The mean total $\mathrm{WBC}$ and neutrophil values were slightly higher than the standard. The PCV, Hb, MCHC and basophils were not significantly different ( $p>0.05)$ between the states. The $R B C$ count was significantly ( $p \leq 0.01)$ lower in Anambra State when compared with other states whereas Enugu State was significantly lower $(\mathbf{p}<0.05)$ than Ebonyi State. The MCV and MCH were significantly higher $(\mathbf{p}<0.05)$ in Anambra State when compared with the other states. However, the WBC, Neutrophil, Lymphocyte and Eosinophil counts are significantly $(p \leq 0.05)$ higher in Ebonyi State when compared with other states (Anambra and Enugu). There was no significant difference $(p \geq 0.05)$ among sexes and ages in all the parameters tested. The values obtained could be used as reference values for pigs in South-eastern Nigeria. The clinical importance of the haematology was discussed.

Key words: haematology, pigs, intensive management, south-eastern Nigeria

\section{INTRODUCTION}

Monogastric (both swine and poultry), has made a very important contribution to the production of animal protein in many countries around the world. As a result of pig's rapid development, and based on the fecundity and growth potential, intensive pig production has played a significant role in meat production and income generation in the tropics (Perez, 1997). Pork is the largest source of meat at the world level, and considering that, due to religious beliefs, pork is not produced and consumed in many countries, its relative importance is even greater in the rest of the world ((Pig International, 1999).

The best indicator of animal's well being and its potential for production is its health status. The intensification of animal agriculture, however, has created complex animal health and production problems for 
which there are no simple and reliable therapeutic and preventive procedures (Radostits et al., 1994). These conditions adversely affect the health or welfare of the animals and impair their homeostatic mechanisms resulting in the body dysfunction which may be fatal (Adenkola et al., 2009). Diseases cause pain and distress to the animal and also significantly reduce their profitability, either through reduced productivity or, in severe cases, through the premature death of infected animals.

The blood consisting of blood cells and plasma fulfils the transport, regulatory, protective and homeostatic functions (Nasyrova et al., 2006). Haematological profiles are important indicators of health and disease in animals and have become indispensible in the diagnosis, treatment or prognosis of many diseases (Mbanasor et al., 2003). Determination of the haematological profiles reflects the physiological responsiveness of the animals to its internal and external environment (Esonu et al., 2001). Anaemia has been described for many diseases and management problems and physiological state (age) in pigs, and determination of the packed cell volume, erythrocyte count and haemoglobin can give an idea of the level of the anaemia.

Haematological parameters of pig have been widely studied and have been reported to vary depending on sex, age, geographical location and experimental procedures (Egbunike and Akusu, 1983., Jain, 1986., Radostits et al., 1994., Aladi et al., 2008), but there is paucity of information on the haematological values of pigs in the south eastern Nigeria.

\section{MATERIALS AND METHODS}

\section{The study area}

The study was carried out in South Eastern Nigeria comprising of five States. South Eastern Nigeria is located in humid and derived savannah zone situated between latitude $6.8^{\circ}$ and $8.5^{\circ} \mathrm{N}$, and longitude $6^{\circ}$ and $10^{\circ} \mathrm{E}$ and the temperature varies usually from $27^{0} \mathrm{C}$ to $35^{\circ} \mathrm{C}$ (Ezedimma, 1976).

\section{Sampling procedure}

Three States (Anambra, Enugu and Ebonyi) were randomly selected for the study. In each of the State, two senatorial zones were selected, and from each senatorial zone, two local government areas were also randomly selected from where the sampling was done.

\section{Experimental Animals}

The animal studied were pigs raised by pig farmers from the study area. The pigs were raised intensively and screened free for endo and ectoparasites (clinically healthy). The predominant breeds of pig were large white/ landrace cross. Pigs of all ages were sampled. The samples were identified according to their state (place of collection), sex and age.

\section{Blood sampling and analysis}

The pigs were restrained and bled through the caudal vena cava as described by Carle and Dewhirst (1942) into bijou bottle containing ethylenediamine tetra-acetic acid (EDTA) as anticoagulant after adequate restraint. The blood samples were analysed for the following parameters: packed cell volume (PCV), red blood cell (RBC) count, haemoglobin ( $\mathrm{Hb})$ concentration and total and differential leucocytes count. The PCV was determined using the microhaematocrit method while the RBC and leucocyte counts were determined using the improved Neubauer counting chamber (Jain, 1986). Smears for differential leucocyte counts were stained by the Leishman technique, and the different cells of leucocyte series were enumerated by the longitudinal counting method. The mean corpuscular volume (MCV), mean 
corpuscular haemoglobin $(\mathrm{MCH})$ and mean corpuscular haemoglobin concentration (MCHC) were calculated from the PCV, $\mathrm{Hb}$ and $\mathrm{RBC}$ count (Baker et al., 2000).

\section{Statistical analysis}

Data were summarized as means \pm standard deviation and were analyzed using one-way analysis of variance and differences in means separated by Duncan's multiple range test (Steel and Torrie, 1980).

\section{RESULTS}

A total of 114 pigs were sampled comprising of 48 males and 66 females comprising of 37 pigs from Anambra, 46 from Enugu and 31 in Ebonyi States. Thirty-eight were piglets and 76 were adults. The mean haematological parameters of the 114 pigs sampled are shown in table I. The parameters compared favourably with reference values (Mitruka et al., 1977) except for MCV and MCH that were slightly lower than the standard. The mean total WBC and neutrophil values were slightly higher than the standard.

When the parameters were compared across the States (Table II), there was no significant difference ( $p>0.05)$ between States among $\mathrm{PCV}, \mathrm{Hb}, \mathrm{MCHC}$ and basophils whereas the RBC count was significantly $(\mathrm{p} \leq 0.01)$ lower in Anambra State when compared with the other States with Enugu State being lower than Ebonyi State. The MCV and $\mathrm{MCH}$ were significantly higher $(\mathrm{p}<0.05)$ in Anambra State compared with the other States.
However, the WBC, Neutrophil, Lymphocyte and Eosinophil counts are significantly $(\mathrm{p} \leq 0.05)$ higher in Ebonyi State when compared with the other States (Anambra and Enugu). There were no significant difference $(\mathrm{p} \geq 0.05)$ between sexes and ages in all the parameters tested (Table III \& IV).

\section{DISCUSSION}

The mean haematological values obtained from this study were similar to the reference values as documented by Mitruka et al., (1977). The high value recorded for WBC may not be unconnected to the fact that the pigs in the tropics were constantly exposed to harsh environmental condition and disease challenge. This increase may be the animal's response to these challenges. The variations in the values obtained when compared with the standard may be attributed to differences in the health status of the animals used, experimental procedures, and differences in age, sex, number and breeds of pig sampled (Mitruka et al., 1977).

Most of the values observed varied significantly $(\mathrm{p} \leq 0.05) \quad$ when compared across States. The variation in $\mathrm{RBC}, \mathrm{MCH}$ and MCV may be attributed to certain factors such as; iron deficiency, vitamin $\mathrm{B}_{12}$ and folate deficiencies, chronic haemolytic anaemia and infectious and chronic diseases eg. African trypanosomosis (Baker et al., 2000). The total leucocyte, lymphocyte, eosinophils and neutrophil values were significantly higher in Ebonyi State than Enugu or Anambra State. 
Table I: Table of the mean haematological values of pigs in Southeastern Nigeria.

\begin{tabular}{lllll}
\hline Parameters & Min. Value & Max. Value & Mean values & *Standard Values \\
& & & & \\
\hline PCV $(\%)$ & 25 & 46 & $35.33 \pm 9.88$ & $36-47$ \\
HB $(\mathrm{g} / \mathrm{dl})$ & 6.05 & 13.2 & $11.08 \pm 2.71$ & $10-15$ \\
$\mathrm{RBC}\left(10^{6} / \mu \mathrm{l}\right)$ & 4.33 & 11.02 & $8.95 \pm 1.95$ & $5-10$ \\
$\mathrm{MCV}(\mathrm{fl})$ & 34.1 & 54.8 & $41.20 \pm 14.77$ & $50-62$ \\
$\mathrm{MCHC}(\mathrm{g} / \mathrm{dl})$ & 24.0 & 37.2 & $32.92 \pm 9.85$ & $25-36$ \\
MCH $(\mathrm{pg})$ & 8.96 & 17.4 & $12.95 \pm 4.08$ & $16-19$ \\
WBC $\left(10^{3} / \mu \mathrm{l}\right)$ & 14.26 & 32.04 & $25.92 \pm 8.08$ & $6-25$ \\
Neutrophil $\left(10^{3} / \mu \mathrm{l}\right)$ & 6.08 & 14.86 & $10.64 \pm 3.09$ & $2-8.85$ \\
Lymphocyte $\left(10^{3} / \mu \mathrm{l}\right)$ & 5.98 & 18.52 & $12.01 \pm 3.36$ & $4-13.8$ \\
Eosinophil $\left(10^{3} / \mu \mathrm{l}\right)$ & 0.48 & 2.04 & $1.29 \pm 0.67$ & $0.18-1.32$ \\
Monocyte $\left(10^{3} / \mu \mathrm{l}\right)$ & 0.69 & 1.94 & $1.44 \pm 0.82$ & $0.3-2.03$ \\
Basophil $\left(10^{3} / \mu \mathrm{l}\right)$ & 0.00 & 1.01 & $0.54 \pm 0.11$ & $0-0.47$
\end{tabular}

*Mitruka, B. M and Rawnsley, H. M. Clinical Biochemical and Haematological reference values in normal experimental animals. Manson Publishing USA. Inc.1977. 
Table II: Table showing the haematological profiles of pigs according to State

\begin{tabular}{lccc}
\hline Parmeters & Enugu State & Anambra State & Ebonyi State \\
\hline $\operatorname{PCV}(\%)$ & $34.38 \pm 7.56^{\mathrm{a}}$ & $36.67 \pm 14.00^{\mathrm{a}}$ & $35.35 \pm 4.31^{\mathrm{a}}$ \\
$\mathrm{Hb}(\mathrm{g} / \mathrm{dl})$ & $10.61 \pm 2.93^{\mathrm{a}}$ & $11.61 \pm 2.72^{\mathrm{a}}$ & $11.35 \pm 1.76^{\mathrm{a}}$ \\
$\mathrm{RBC}\left(10^{6} / \mu \mathrm{l}\right)$ & $9.14 \pm 1.42^{\mathrm{a}}$ & $7.41 \pm 1.44^{\mathrm{b}}$ & $11.41 \pm 1.23^{\mathrm{c}}$ \\
$\mathrm{MCV}(\mathrm{fl})$ & $38.54 \pm 9.76^{\mathrm{a}}$ & $50.05 \pm 18.98^{\mathrm{b}}$ & $31.27 \pm 4.65^{\mathrm{c}}$ \\
$\mathrm{MCHC}(\mathrm{g} / \mathrm{dl})$ & $31.47 \pm 8.16$ & $35.01 \pm 12.44$ & $32.82 \pm 7.94$ \\
$\operatorname{MCH}(\mathrm{pg})$ & $11.88 \pm 3.60^{\mathrm{a}}$ & $15.95 \pm 3.79^{\mathrm{b}}$ & $10.02 \pm 1.61^{\mathrm{c}}$ \\
WBC$\left(10^{3} / \mu \mathrm{l}\right)$ & $25.15 \pm 9.11^{\mathrm{a}}$ & $24.01 \pm 7.45^{\mathrm{a}}$ & $31.28 \pm 3.04^{\mathrm{b}}$ \\
Neutrophil $\left(10^{3} / \mu \mathrm{l}\right)$ & $10.65 \pm 2.72^{\mathrm{a}}$ & $10.19 \pm 2.56^{\mathrm{a}}$ & $13.52 \pm 2.94^{\mathrm{b}}$ \\
& & & \\
& & $11.40 \pm 2.03^{\mathrm{a}}$ & $14.35 \pm 2.73^{\mathrm{b}}$ \\
Lymphocyte $\left(10^{3} / \mu \mathrm{l}\right)$ & $11.95 \pm 3.28^{\mathrm{a}}$ & $1.12 \pm 0.48^{\mathrm{a}}$ & $1.75 \pm 0.71^{\mathrm{b}}$ \\
Eosinophil $\left(10^{3} / \mu \mathrm{l}\right)$ & $1.23 \pm 0.73^{\mathrm{a}}$ & $1.26 \pm 0.58^{\mathrm{a}}$ & $2.18 \pm 0.86^{\mathrm{b}}$ \\
Monocyte $\left(10^{3} / \mu \mathrm{l}\right)$ & $1.26 \pm 0.82^{\mathrm{a}}$ & $0.04 \pm 0.87^{\mathrm{a}}$ & $0.07 \pm 0.15^{\mathrm{a}}$ \\
\hline Basophil $\left(10^{3} / \mu \mathrm{l}\right)$ & $0.06 \pm 0.11^{\mathrm{a}}$ & &
\end{tabular}

$\mathrm{a} b$ and $\mathrm{c}$ : means within same row with different superscripts are significantly different $(\mathrm{p}<0.05)$. 
Table III. Table showing the haematological profiles of pigs according to age

\begin{tabular}{lcc}
\hline PARAMETERS & \multicolumn{2}{c}{ AGE } \\
& Piglets & Adult \\
\hline PCV $(\%)$ & $31.36 \pm 7.1$ & $35.89 \pm 10.10$ \\
Hb $(\mathrm{g} / \mathrm{dl})$ & $9.60 \pm 1.78$ & $11.29 \pm 2.76$ \\
RBC $\left(10^{6} / \mu \mathrm{l}\right)$ & $8.94 \pm 1.69$ & $8.95 \pm 2.76$ \\
MCV $(\mathrm{fl})$ & $25.54 \pm 5.59$ & $27.04 \pm 8.38$ \\
MCHC $(\mathrm{g} / \mathrm{dl})$ & $35.60 \pm 9.16$ & $41.99 \pm 15.26$ \\
MCH $(\mathrm{pg})$ & $31.79 \pm 7.44$ & $33.08 \pm 10.16$ \\
WBC $\left(10^{3} / \mu \mathrm{l}\right)$ & $27.73 \pm 2.72$ & $27.08 \pm 4.17$ \\
Neutro $\left(10^{3} / \mu \mathrm{l}\right)$ & $11.61 \pm 3.01$ & $10.46 \pm 3.11$ \\
Lymph $\left(10^{3} / \mu \mathrm{l}\right)$ & $12.21 \pm 2.52$ & $13.97 \pm 3.52$ \\
Eosino $\left(10^{3} / \mu \mathrm{l}\right)$ & $1.79 \pm 0.57$ & $1.20 \pm 0.65$ \\
Monocy $\left(10^{3} / \mu \mathrm{l}\right)$ & $1.74 \pm 0.46$ & $1.39 \pm 0.86$ \\
Basoph $\left(10^{3} / \mu \mathrm{l}\right)$ & $0.38 \pm 0.11$ & $0.06 \pm 0.11$ \\
\hline
\end{tabular}


Table IV. Table showing the haematological profiles of pigs according to sex

\begin{tabular}{lcc}
\hline PARAMETERS & \multicolumn{2}{c}{ MEX } \\
& $34.18 \pm 9.34$ & $35.91 \pm 9.88$ \\
PCV $(\%)$ & $10.74 \pm 2.25$ & $11.25 \pm 2.90$ \\
Hb $(\mathrm{g} / \mathrm{dl})$ & $9.12 \pm 1.94$ & $8.86 \pm 1.97$ \\
RBC $\left(10^{6} / \mu \mathrm{l}\right)$ & $26.39 \pm 5.90$ & $27.10 \pm 9.00$ \\
MCV $(\mathrm{fl})$ & $39.21 \pm 15.37$ & $42.20 \pm 14.46$ \\
MCHC $(\mathrm{g} / \mathrm{dl})$ & $33.89 \pm 10.56$ & $32.44 \pm 9.51$ \\
MCH $(\mathrm{pg})$ & $27.16 \pm 4.10$ & $25.75 \pm 4.07$ \\
WBC $\left(10^{3} / \mu \mathrm{l}\right)$ & $10.85 \pm 3.37$ & $11.54 \pm 2.99$ \\
Neutro $\left(10^{3} / \mu \mathrm{l}\right)$ & $12.69 \pm 3.16$ & $11.66 \pm 3.45$ \\
Lymph $\left(10^{3} / \mu \mathrm{l}\right)$ & $1.59 \pm 0.74$ & $1.14 \pm 0.58$ \\
Eosino $\left(10^{3} / \mu \mathrm{l}\right)$ & $1.63 \pm 0.74$ & $1.35 \pm 0.85$ \\
Monocy $\left(10^{3} / \mu \mathrm{l}\right)$ & $0.40 \pm 0.09$ & $0.06 \pm 0.11$ \\
Basoph $\left(10^{3} / \mu \mathrm{l}\right)$ &
\end{tabular}

Elevation in leucocyte count in this study could be attributed to infectious diseases and tissue damage (Baker et al., 2000). Leucocytosis in animals have also been attributed to stress (Buckham-Sporer et al., 2008) and is suggested to be due to mobilisation of leucocyte from their pool to the peripheral circulation apparently due to its inhibitory role on circulating corticosteroids which is known to increase in animal under stress and cause leucocytosis (Adenkola et al., 2009).

The values obtained did not vary significantly between sexes (male and female) and between ages (piglet and adult). This result is in agreement with the report of Aladi et al., (2008) that age has no association with haematological values. However, this does not agree with
Egbunike and Akusu (1983), who reported that sex and age significantly affect blood values in pigs. According to Egbunike and Akusu (1983), the total white blood cell counts were not affected by breed and sex but the other haematological parameters exhibited various degrees of response to these two variables, the males of each breed tending to have higher values than the females.

Haematological parameters are good indicators of the physiological and pathological changes in the animals (Hawkey and Dennett, 1989, Adenkola and Durotoye, 2004), and are also an excellent medium for the measurement of potential biomarkers (Adenkola et al., 2009). The blood consisting of blood cells and plasma fulfils the transport, regulatory, 
protective and homeostatic functions (Nasyrova et al., 2006). Blood parameters are indispensible in the diagnosis, treatment or prognosis of many diseases (Mbanasor et al., 2003). Normal blood parameters of pigs have been reported from many parts of the world including Nigeria.

Haematological values are of great diagnostic importance in practical husbandry since they reflect the response of the animal to its environment and diseases. They can also act as useful aids to prognosis and may reveal adverse conditions even when the animal did not display obvious clinical signs of ill health. A deviation from normal haematological values is an indication of what is happening in the body.

In conclusion, the closeness of the hematological values obtained from the pigs to the reference values is an indication that the result may be used as base line data for pigs reared in South Eastern Nigeria. The result is also a demonstration that pigs used in this experiment were apparently healthy animals

\section{ACKNOWLEDGEMENT}

We are grateful to the University of Nigeria Administration and more especially to the Senate Committee on Research Grants for funding this project (Senate Research Grants No 07/21). The authors acknowledge the cooperation of the Directors of Veterinary Services in Anambra, Ebonyi and Enugu States in the course of this study. We also appreciate the efforts of the Faculty Technologists and the Secretariat of the Department of Veterinary Public Health and Preventive Medicine for their roles in actualization of this study.

\section{REFERENCES}

ADENKOLA, A.Y and DUROTOYE, L. A. (2004). Haematological study during pre-partum and postpartum periods in brown savannah does in Zaria. Proceedings of $38^{\text {th }}$ Annual Conference, Agricultural Association of Nigeria, pp 538540.

ADENKOLA. A.Y., AYO, J.O., SACKEY A.K.B and ADELAIYE, A.B. (2009). Haematological and serum biochemical changes in pigs administered with ascorbic acid and transported by road for four hours during the harmattan season. Journal of Cell and Animal Biology. 3(2): 021-028.

ALADI, N. O., OKEUDO, N. J., OKOLI, I. C and AKANNO, E. C. (2008). Reproductive and haematological characteristics of the Nigerian indigenous and large white pigs in a humid tropical environment. Asian J Anim Vet Advances. 3(1). 17-23.

BAKER, F. J., SILVERSTON, R. E. and PALLISTER, C. J. (2000). Baker and Silverton's Introduction to Medical Laboratory Technology, $7^{\text {th }}$ Edition, Sam-Adex Printer, Felele Rab, Ibadan- Nigeria.

BUCKHAM-SPORER, K. R., WEBER, P. S., BURTON, J. L., EARLEY, B. and CROWE, M. A. (2008). Transportation of young beef bulls alters circulating physiological parameters that may effective biomarkers of stress. $J$ Anim Sci. 86; 1325 - 1334.

CARLE B. N and DEWHIRST Wm. H. Jr. (1942). A method for bleeding 
swine. J Am Vet Med Assoc. 101: 495-496.

EGBUNIKE GN, and AKUSU MO. (1983). Breed and sex influences on porcine haematological picture under hot humid climatic conditions.Vet Res Commun. 6(2):103-109.

EZEDIMMA, F. O. C. (1976). Weather and annual crop production in rainforest zone of Southern Nigeria. In: Anazodo G. N., Odigboh E. U., eds, Appropriate approaches for accelerated food production in the rainforest zones of Nigeria. Proc. Symp., Dept of Agric. Engineering, University of Nigeria, Nsukka, Nigeria, 10-11 September, 1976, p. 59-69.

ESONU, B. O., ENENALOM, O. O., UDEDIBIE, A. B. I., HERBERT, U., EKPOR, C. F., OKOLI, I. C and IHEUKWUMERE, F. C. (2001). Performance and blood chemistry of weaner pigs fed raw mucuna (velvet bean) meal. Trop. Anim. Prod Invest. 4: 49-55.

HAWKEY, C. N and DENNETT, A. (1989). A colour atlas of comparative veterinary haematology. Wolfe Medical Publication, England. 192 pp.

JAIN, N. C. (1986). Schalm's Veterinary Haematology. $4^{\text {th }}$ edition. Lea and Febigir, Philadelphia.

MBANASOR, U.U., ANENE, B.M., CHIME, A.B., NNAJI, T.O., EZE, J.I and EZEKWE, A.G. (2003). Haematology of normal and trypanosome infected Muturu cattle in southeastern Nigeria. Nig $J$ Anim Prod. 30(2); 236-241.
MITRUKA, B. M and RAWNSLEY, H. M. (1977). Clinical Biochemical and Haematological reference values in normal experimental animals. Manson Publishing USA. Inc.

NASYROVA, D. I., YA. SAPRONOVA, A., NIGMATULLINA, R. R. and UGRUMOV, M. V. (2006). Changes in blood plasma volume in rats during ontogenesis. Russ $J$ Develop Biol. 27;1062-3604

PÉREZ, R. (1997). Feeding pigs in the tropics. FAO Animal Production and Health Paper 132. 185pp.

PIG INTERNATIONAL. (1999). Positive demand patterns for pork Watt Publishing Company. Mt. Morris Illinois, USA. Vol. 29(6):15-16.

STEEL R. G. D and TORRIE, J. H. (1980). Principles and Procedures of Statistics; A biometrical approach. $2^{\text {nd }}$ edition. McGrawHill and Book Company, New York.

RADOSTITS, O. M., BLOOD, D. C and GAY, C. C. (1994). Veterinary Medicine: A textbook of Diseases of Cattle, Sheep, Pigs, Goats and Horses. W.B Saunders Company. London. 